\title{
HANEHALKI SORUMLUSU VE YOKSULLUK: PROBITT MODEL
}

\section{Prof. Dr. Tuba YAKICI AYAN}

\section{Dr. Öğr. Üyesi Nurdan DEĞİRMENCI*}

\begin{abstract}
ÖZET
Bu çalışmada Türkiye'de yoksulluğu etkileyen hanehalkı sorumlusuna ilişkin demografik faktörler probit analiz yöntemi ile belirlenmiştir. Analiz verileri Türkiye İstatistik Kurumuna ait 2017 yılı hanehalkı gelir ve yaşam koşulları araştırması fert ve hane anketlerinden sondaj ve birleștirme yoluyla elde edilmiştir. Ardından 22869 kayıt arasından bölgelere göre tabakalı örnekleme yöntemi ile 761 kayıt seçilmiştir. Yapılan analizler sonucunda, hanehalkı sorumlusunun faaliyet durumunun, genel sağllk durumunun ve hane nüfusunun ailenin yoksulluk olasılı̆̆ını pozitif etkilediği, buna karşın hanehalkı sorumlusunun eğitim düzeyinin, yaşının ve kadın olmasının ise negatif etkilediği belirlenmiştir.
\end{abstract}

Anahtar Kelimler: Yoksulluk, Demografik Faktörler, Probit Model.

Jel Kodlart: C35, I32, J12.

\section{HOUSEHOLD HEAD AND POVERTY: PROBIT MODEL}

\begin{abstract}
In this study, demographic characteristics of the household head which affect poverty of household in Turkey was determined by probit model method. Analysis data were obtained from the 2017 household income and living conditions survey of Turkish Statistical Institute by drilling and merging from individual and household surveys. Then, among the 22869 records, 761 records were selected by stratified sampling method according to regions. Among the variables considered, the activity level, the general health status of the household head and the household population positively affected the poverty probability of the household, whereas the level of education of the household head, his/her age and her being a woman had a negative impact on poverty.
\end{abstract}

Keywords: Poverty, Demographic Factors, Probit Model.

Jel Codes: C35, I32, J12.

\footnotetext{
* Karadeniz Teknik Üniversitesi, İ.İ.B.F., Ekonometri Bölümü, Trabzon, Türkiye. E-mail: ayan@ktu.edu.tr

* Recep Tayyip Erdoğan Üniversitesi, F.U.B.Y.O., Uluslararası Ticaret ve Lojistik Bölümü, Türkiye. E-mail: nurdan.degirmenci@erdogan.edu.tr
}

\section{Makale Gecmisii/Article History}




\section{GİRIŞ}

Yoksulluk literatürdeki pek çok tanımından yola çıkılarak kısaca "temel bir yaşam standardı için sahip olunması gereken temel ihtiyaçların karşılanamaması durumu" olarak ifade edilebilir. Yoksulluğun ölçülmesinde tek boyutlu, çok boyutlu, göreli veya mutlak olmak üzere birçok yöntem kullanılmaktadır (Greeley, 1994; Wright, 1996; Alkire vd., 2015; United Nation, 2017). Tek boyutlu yöntemlerden en yaygın kullanılan ikisi gelir yoksulluğu ve harcama yoksulluğudur. Geliri önceden belirlenmiş bir düzeyin altında olan bireyler gelir yoksulu iken harcama düzeyi belli bir değerin altında kalanlar ise harcama yoksulu olarak sınıflandırılmaktadır. Burada sözü edilen önceden belirlenmiş değer sabit olabileceği gibi toplumdaki diğer bireylerin gelir ya da harcamalarının belli bir yüzdesi olarak belirlenmiş de olabilir. Bu çalışmada yoksulluğun ölçülmesinde tek boyutlu ve mutlak bir ölçüt olan ve TÜRK-İŞ tarafından aylık olarak kamuoyuna açıklanan yoksulluk sınırı kullanılmaktadır. Yoksulluk sınırı yeterli hayat standardında yaşayabilmek için gerekli olan minimum gelir miktarını ifade eden bir değerdir. Bütün dünyada olduğu gibi Türkiye'de de yoksulluğun azaltılması temel önceliklerden biridir. Bunun için yoksulluğun nedenlerinin ve yoksulluğu arttıran faktörlerin bilinmesi ve bunlara yönelik önlemlerin alınması gerekmektedir.

Türkiye'de hane boyutunda yoksulluğun ölçülmesi ve azaltılmasına yönelik yapılmış sınırlı sayıdaki kantitatif çalışmalardan bazıları şunlardır. Kızılgöl (2008), çalışmasında yoksulluğun en önemli belirleyicilerinin aile bireylerinin eğitim durumu, hane büyüklüğü ve hanenin konumu olduğunu ifade etmiştir. Aydın ve Güloğlu (2011), eğitim düzeyi çok düşük kişilerde, yevmiyeli veya geçici işler ile tarım sektöründe çalışanlarda, 60 yaş üzeri olanlar ve kadınlar arasında yoksulluğun çok yaygın olduğunu belirlemişlerdir. Şengül ve Fisunoğlu (2012), yoksulluğun 4 ve daha fazla bireyli hanelerde daha yüksek bulunduğu, boşanmış ve eşi ölmüş kadınların evli kadınlara nazaran yoksulluğu daha yoğun yaşadıklarını saptamışlardır. Ayrıca bu çalışmada 65 yaş üstü kadınların bu yaş grubundaki erkeklerden daha yoksul olduğu belirlenmiştir. Limanlı (2015) çalışmasında hanehalkının sağlık koşulları ve eğitim düzeyini yoksulluğu etkileyen önemli değişkenler olarak bulurken, hanehalkı sorumlusu kadın olanların yoksulluğa daha açık olduğunu tespit etmiştir. Bunlara ilaveten, Topalhan ve Yeşilkaya (2017) ise kadın yoksulluğunu istihdamdan daha çok eğitim düzeyinin pozitif yönde etkilediğini ortaya koymuşlardır. Yeni bir çalışma olarak Değirmenci (2020) ise Türkiye'de bölgelere göre yoksulluğun hanehalkı sorumlusuna dair belirleyicilerini incelemiştir. Sonuçta bölgelere göre bazı farklılıklar olmakla birlikte hanehalkı sorumlusunun cinsiyeti, medeni durumu, resmi nikâhlı olup olmaması ve sağlık durumu değişkenleri hiçbir bölgede anlamlı değilken, eğitim seviyesi bütün bölgeler için anlamlı bulunmuştur.

Dünya'da yoksullukla ilgili yapılan ve demografik faktörleri dikkate alan bazı çalışmalar ise şöyle özetlenebilir. Shirazi (1995), hanehalkının yoksul olma olasılığının, hanehalkı sorumlusunun kazancı ve eğitim düzeyi ile negatif, hane nüfusu ile pozitif ilişkili olduğunu tespit etmiştir. Mukherjee ve Benson (1998), özellikle kadınların eğitim düzeyindeki yükselmenin ve hanehalkı işgücünün tarım yerine ticaret ve hizmet sektörüne tahsis edilmesinin, Malavi'deki yoksulluğun azaltılmasında etkili olacağını 
Yönetim ve Ekonomi Araștırmaları Dergisi / Journal of Management and Economics Research

Cilt/Volume: 19 Sayl/Issue: 1 Mart/March 2021 ss./pp. 77-87

T. Y. Ayan, N. Değirmenci, Doi: http://dx.doi.org/10.11611/yead.675290

belirlemişlerdir. Roberts (2001), Güney Afrika'daki yoksulluğu dinamik bir bakış açısıyla incelediği makalesinde özellikle kırsal yerleşim yerlerinde ve sorumlusu kadın olan ailelerde yoksulluğun hem oransal hem de derinlik olarak 1993 ile 1998 arasında sürekli arttığını göstermiştir. Alisjahbana ve Yusuf (2003), Endonezya'da eğitim seviyesinin artmasının ve hanehalkı sorumlusunun evli olmasının yoksulluğu azalttığını, hane nüfusunun artmasının ise yoksulluğu arttırdığını ve ayrıca ailenin yaşadığı bölgenin de yoksulluk üzerinde etkili olduğunu ifade etmişlerdir. Geda vd. (2005), çalışmalarında yoksulluk durumunun, hem kırsal hem de kentsel alanda eğitim düzeyiyle, hane nüfusuyla ve tarımsal faaliyetlerle güçlü bir ilişkisi olduğunu belirlemişlerdir. Okwi vd. (2007), coğrafi faktörlerin yoksulluk üzerindeki etkilerini mekânsal regresyon teknikleri ile araştırdıkları çalışmalarında, eğitim, toprak tipi, kamu kaynaklarına uzaklık, rakım, arazi kullanım şekli ve demografik değişkenlerin yoksulluğun mekânsal örüntülerini açıklamada önemli olduklarını belirlemişlerdir. De La Rosa (2008), doktora tez çalışmasında, ABD'de yaşayan Latinlerin yoksulluklarını etkileyen en önemli faktörlerden birinin düşük eğitim düzeyi ve sağlık durumları olduğunu verilerle ve analiz bulgularıyla ortaya koymuştur. Rajaram (2009), Hindistan için yapmış olduğu çalışmasında hanehalkı sorumlusunun cinsiyetinin yoksulluğun belirleyicilerinden biri olduğunu belirlemiştir. Hanehalkı sorumlusu kadın olan ve kalabalık ailelerde yoksulluk olasıllı̆̆ daha yüksek iken eğitim düzeyi ise yoksulluğu azaltan bir faktör olarak bulunmuştur. Sadiq (2010), Pakistan'da hanehalkı sorumlusuna dair özelliklerin yoksulluk durumu üzerinde çok etkili olduğunu ifade etmiştir. Elde ettiği çeşitli bulguların yanı sıra hanehalkı sorumlusunun yaşının ailenin yoksul olma riskini azalttığı bulgusuna ulaşmıştır. Achia vd. (2010), Kenya'da hanehalkı yoksulluğunu araştırdıkları çalışmalarında, hanehalkı sorumlusunun yaşının hanenin yoksul olma olasılığını arttırdığını bulmuştur. Sekhampu (2012), Güney Afrika'da hanehalkı sorumlusunun yaşının, eğitim düzeyinin ve evli olmasının yoksulluk olasılığını azalttığını ortaya koymuştur. Dartanto ve Nurkholis (2013), Endonezya için eğitim düzeyi, hane nüfusu, fiziki varlıklar, istihdam durumu, sağlık koşulları, elektriğe erişim faktörlerinin yoksulluğun belirleyicileri olduğunu ifade etmişlerdir. Whelan vd. (2014) ise sosyal sınıf, eğitim ve yaş gibi değişkenlerin yoksulluk üzerindeki etkisinin düşük gelirli ülkelerde orta ve yüksek gelirli ülkelere kıyasla daha etkili olduklarını bulmuşlardır. Rodriguez (2015), Meksika için yaptığı çalışmasında yoksul olma olasılığını hanehalkı sorumlusunun yaşı ve eğitim düzeyi azaltırken hane nüfusunun arttırdığını, hanehalkı sorumlusunun cinsiyetinin ise etkilemediğini belirtmiştir. Islam vd. (2017), Bangladeş'te hanehalkı sorumlusunun cinsiyetinin hanelerin yoksulluğu üzerinde önemli etkisi yokken yaşı, eğitim düzeyi ve medeni durumunun önemli etkileri olduğunu belirlemişlerdir. Mohd vd. (2018), Malezya'da yaşa göre yoksulluk insidansını araştırdıkları çalışmalarında, 2009 ve 2012 yılı hanehalkı gelir anketlerini kullanarak, yaşlı hanehalkı sorumluları için yoksulluk oranının nispeten düşük, bunun aksine özellikle hane sorumlusunun yaşlı kadın ve resmi olarak evli olmadığı durumda ise yoksulluk oranının yüksek olduğunu ortaya koymuşlardır.

Yukarıda örnekleri verilmiş olan literatür dışında hanehalkı yoksulluğu ile ilgili çok sayıda farklı değişken ve yöntem kullanılarak yapılmış olan pek çok çalışma ile karşılaşılmaktadır. Ancak bu 
çalışmada özellikle hanehalkı sorumlusunun demografik özellikleri üzerinde odaklanılmıştır. Çünkü Türkiye'de çalışma alanında ve toplumun hemen her kesiminde yönetici konumundaki sorumluların uygulamalar ve sonuçlar üzerindeki etkisinin oldukça baskın olduğu gözlemlenmektedir. Bu durumun Türk aile yapısında da genellikle geçerli olduğu düşüncesinden hareketle bu çalışmada, hanehalkı sorumlusunun demografik özelliklerinin hanelerin yoksulluğu üzerindeki etkilerini incelemek için probit model yaklaşımı kullanılmıştır.

\section{ARAŞTIRMADA KULLANILAN DEĞISSKENLER VE YÖNTEM}

Bu çalışmada kullanılan veriler TÜíK'e ait 2017 yılı hanehalkı gelir ve yaşam koşulları araştırması fert ve hane anketlerinden sondaj ve birleştirme yoluyla elde edilmiştir. Ardından 22869 kayıt arasından bölgelere göre tabakalı örnekleme yöntemi ile 761 kayıt seçilmiştir.

Çalışmada haneler yoksulluk sınırının altında olanlar ve üstünde olanlar şeklinde 2 kategoriye ayrılmıştır. Kullanılan değişkenler Tablo 1'de görülmektedir.

Tablo 1. Çalışmada Kullanılan Değişkenler

\begin{tabular}{|c|c|}
\hline Değişkenler & Açıklama \\
\hline Bağımlı Değişken & $\begin{array}{l}\text { 0: yoksul olmayan hane } \\
\text { 1: yoksul hane }\end{array}$ \\
\hline \multicolumn{2}{|l|}{ Bağımsız Değişken } \\
\hline $\mathbf{H N}$ & Hane nüfusu \\
\hline $\mathbf{Y}$ & $\begin{array}{l}\text { Hanehalkı sorumlusunun yaşı; } \text { Dünya Sağlık Örgütünün } 2018 \text { yılı öncesi } \\
\text { sinıflandırmasına uygun olarak 0-44 genç, 45-59 orta yaş, 60- yaşlı }\end{array}$ \\
\hline CNS & Hanehalkı sorumlusunun cinsiyeti; 1: Erkek, 2: Kadın \\
\hline FD & $\begin{array}{l}\text { Hanehalkı sorumlusunun esas faaliyet durumu; 1: Çalışıyor, 2: İş arıyor 3: Emekli- } \\
\text { işten ayrılmış }\end{array}$ \\
\hline MD & Hanehalkı sorumlusunun medeni durumu; 1: Evli, 2: Bekâr, 3:Diğer \\
\hline $\mathbf{R N}$ & Hanehalkı sorumlusunun resmi nikâhının olup olmadığı; 1: Evet, 2: Hayır \\
\hline ES & $\begin{array}{l}\text { Hanehalkı sorumlusunun eğitim seviyesi; 1: Okuryazar değil, ilkokul; 2: Ortaöğretim, } \\
\text { lise 3: Lisans, Lisansüstü }\end{array}$ \\
\hline SD & Hanehalkı sorumlusunun genel sağlık durumu; 1:İyi; 2: Orta; 3: Kötü \\
\hline
\end{tabular}

Tablo 2'de 761 birimlik örnekleme ait tanımlayıcı istatistikler verilmektedir. Tablodan görüldüğ̈̈ gibi hanehalkı nüfusu ve hanehalkı sorumlusunun yaşı geniş bir aralıkta değişmektedir. Bu değişkenlere ait ortalama ve medyan değerlerinin birbirine yakın çıkmış olmaları dağılımın simetriğe yakın olduğuna işaret etmektedir. Örneklemi oluşturan ailelerin gelir düzeyleri ise sağa çarpık asimetrik bir dağı̆lım göstermektedir. Yani örneklemde düşük gelir düzeyinde bir yoğunluk olduğu söylenebilir. Örneklemdeki hanehalkı sorumlularının çok büyük bir oranı erkeklerden oluşmaktadır. Faaliyet durumuna bakıldığında hanehalkı sorumlularının üçte ikisinin çalışmakta olduğu görülmektedir. Medeni durum ve resmi nikâh değişkenlerine dair gözlemlerin büyük bir kısmı tek bir kategoride yer alıyor olsalar da bu değişkenler zaten probit analizin başlangıcında elenmişlerdir. Eğitim seviyesi ve sağlık 
durumu değişkenlerinde ise kategori büyüklükleri birbirinden çok farklı değildir. Bu anlamda dengeli bir dağılım gözlemlenmektedir.

Tablo 2. Örneklem İstatistikleri

\begin{tabular}{|c|c|c|c|c|c|}
\hline \multicolumn{2}{|l|}{ Ins } & Minimum & Maksimum & Ortalama & Medyan \\
\hline \multicolumn{2}{|l|}{ Hane Nüfusu } & 1 & 11 & 3,68 & 4 \\
\hline \multicolumn{2}{|l|}{ Yaş } & 21 & 94 & 47,38 & 46 \\
\hline \multicolumn{2}{|l|}{ Gelir } & 3700,00 & 329139,00 & 41365,8962 & 30000,0000 \\
\hline & & \multicolumn{4}{|c|}{ Yüzde } \\
\hline \multirow[t]{2}{*}{ Cinsiyet } & Erkek & \multicolumn{4}{|c|}{95,4} \\
\hline & Kadın & \multicolumn{4}{|c|}{4,6} \\
\hline \multirow{3}{*}{$\begin{array}{l}\text { Faaliyet } \\
\text { Durumu }\end{array}$} & Çalışıyor & \multicolumn{4}{|c|}{67} \\
\hline & İş Arıyor & \multicolumn{4}{|c|}{3,8} \\
\hline & $\begin{array}{l}\text { Emekli/İşten } \\
\text { Ayrılmış }\end{array}$ & \multicolumn{4}{|c|}{29,2} \\
\hline \multirow{3}{*}{$\begin{array}{l}\text { Medeni } \\
\text { Durum }\end{array}$} & Evli & \multicolumn{4}{|c|}{99,1} \\
\hline & Bekâr & \multicolumn{4}{|c|}{0,7} \\
\hline & Diğer & \multicolumn{4}{|c|}{0,2} \\
\hline \multirow[t]{2}{*}{ Resmi Nikâh } & Evet & \multicolumn{4}{|c|}{98,9} \\
\hline & Hayır & \multicolumn{4}{|c|}{1,1} \\
\hline \multirow[t]{3}{*}{$\begin{array}{l}\text { Eğitim } \\
\text { Seviyesi }\end{array}$} & $\begin{array}{l}\text { Okuryazar } \\
\text { değil, ilkokul }\end{array}$ & \multicolumn{4}{|c|}{43,1} \\
\hline & $\begin{array}{l}\text { Ortaöğretim, } \\
\text { lise }\end{array}$ & \multicolumn{4}{|c|}{30,9} \\
\hline & $\begin{array}{l}\text { Lisans, } \\
\text { lisanstü }\end{array}$ & \multicolumn{4}{|c|}{26,0} \\
\hline \multirow{3}{*}{$\begin{array}{l}\text { Sağlık } \\
\text { Durumu }\end{array}$} & İyi & \multicolumn{4}{|c|}{68,3} \\
\hline & Orta & \multicolumn{4}{|c|}{23,4} \\
\hline & Kötü & \multicolumn{4}{|c|}{8,3} \\
\hline
\end{tabular}

Çalışmada probit model yaklaşımı kullanılmıştır. Probit model nitel bir bağımlı değişkenin bir veya daha fazla bağımsız değişkenle açıklandığı bir modeldir. Burada bağımlı değişkenin belli bir değeri alma yani belli bir kategoriye girme olasıllğı tahmin edilmektedir. Bu tahmin için kümülatif normal dağılım kullanılmaktadır.

Burada $\Phi(X \beta)$ kümülatif standart normal dağılımı göstermek üzere, belli x değerleri için bağımlı değişkenin 1'e eşit olma olasılı̆̆ı aşağıdaki gibi hesaplanabilir.

$$
\begin{aligned}
& \operatorname{Pr}(y=1 \mid x)=\Phi(x \beta) \\
& \Phi(X \beta)=\int_{-\infty}^{x \beta} \Phi(z) d z=\pi \\
& \Phi(z)=\frac{1}{\sqrt{2 \pi}} e^{\frac{z^{2}}{2}} \\
& \Phi^{-1}(\pi)=X \beta=\beta_{0}+\beta_{1} x_{1}+\cdots \ldots+\beta_{n} x_{n}
\end{aligned}
$$




\section{BULGULAR}

Başlangıçta yapılan tek değişkenli analizlerde resmi nikâh ve medeni durum değişkenleri yoksullukla ilişkili bulunmamıştır. Kalan değişkenlerle yapılan analiz sonuçları ve elde edilen probit model aşağıdaki gibidir.

$$
\text { PROBIT }_{i}=0,762+0,448 H N-0,351 Y-0,816 C N S+0,618 F D-0,900 E S+0,119 S D
$$

Tablo 3. Probit Model Parametre Tahminleri

\begin{tabular}{|l|l|l|l|l|l|l|l|}
\hline Parametre Tahminleri & Parametre & Tahmin & Std. Hata & Z & \multicolumn{2}{l|}{ P- } & \multicolumn{2}{|c|}{ 95\% Güven Düzeyi } \\
\cline { 4 - 8 } & & & & & & Alt Sinır & Üst Sınır \\
\hline PROBIT & HN &, 448 &, 022 & 20,221 &, 000 &, 405 &, 492 \\
\cline { 2 - 8 } & Y &,- 351 &, 044 & $-8,053$ &, 000 &,- 437 &,- 266 \\
\cline { 2 - 8 } & CNS &,- 816 &, 207 & $-3,953$ &, 000 & $-1,221$ &,- 412 \\
\cline { 2 - 8 } & FD &, 618 &, 043 & 14,296 &, 000 &, 534 &, 703 \\
\cline { 2 - 8 } & ES &,- 900 &, 026 & $-34,998$ &, 000 &,- 950 &,- 849 \\
\cline { 2 - 8 } & SD &, 119 &, 047 & 2,502 &, 012 &, 026 &, 212 \\
\cline { 2 - 8 } & Sabit &, 762 &, 261 & 2,916 &, 004 &, 501 & 1,023 \\
\hline
\end{tabular}

Elde edilen bulgulara göre değişkenlerin tamamı anlamlıdır. Ayrıca model ki-kare değeri de modelin veriye uyumunun iyi olduğunu göstermiştir.

Tablo 4. Ki-Kare Değeri

\begin{tabular}{|c|c|c|c|c|}
\hline \multicolumn{5}{|c|}{ Ki-Kare Testi } \\
\hline \multicolumn{2}{|c|}{} & Ki-Kare & $\begin{array}{c}\text { Serbestlik } \\
\text { Derecesi }\end{array}$ & P- \\
\hline PROBIT & $\begin{array}{c}\text { Pearson Uyum İyiliği } \\
\text { Testi }\end{array}$ & 694,3877 & 753 &, 9375 \\
\hline
\end{tabular}

Model katsayılarının yorumlanması için aşağıdaki gibi marjinal etkiler yaklaşımı kullanılmıştır.

$$
\begin{aligned}
& \overline{(P R O B I T)}=0,762+0,448 * 3,6794-0,351 * 1,7438-0,816 * 1,0460+0,618 * 1,6268 \\
& -0,900 * 1,8292+0,119 * 2,3508=0,5836 \\
& P(Z<\overline{(P R O B I T)})=0,719
\end{aligned}
$$

Çalışmadan elde edilen sayısal bulgular aşağıdaki gibidir:

- Hanehalk1 sayısı 1 kişi artınca yoksulluk olasılı̆̆ı \%32,21 $(0,448 * 0,719=0,3221)$ artar.

- Hanehalkı sorumlusunun yaşı gençten orta yaşa ya da orta yaştan yaşlılığa çıktığında yoksulluk olasılı̆ 1 \% $25.24(-0.351 * 0.719=-0.2524)$ azalır.

- Hanehalkı sorumlusu kadın olan ailelerin yoksul olma olasılığı erkek olanlara göre \%58.67 ($0.816 * 0.719=-0.5867)$ daha düşüktür.

- Hanehalkı sorumlusu iş aramakta olanların yoksul olma olasılığı halen bir işte çalışmakta olanlara göre $\% 44.43(0.618 * 0.719=0.4443)$ daha yüksektir. 
- Hanehalk1 sorumlusunun eğitim seviyesi arttıkça yoksul olma olasılığ $1 \% 64.71(-0.9 * 0.719=$ $-0.6471)$ azalmaktadır.

- Hanehalk1 sorumlusunun genel sağlık durumu kötüleştikçe ailenin yoksul olma olasıllığı \%8.56 $(0.119 * 0.719=0.0856)$ artmaktadır.

\section{SONUÇ VE TARTIŞMA}

Bu çalışmada 2017 yılı verilerine dayanarak Türkiye'de ailelerin yoksulluk olasılığını etkileyen hanehalkı sorumlusuna ilişkin demografik faktörler incelenmiş ve önemli bulgulara ulaşılmıştır.

Elde edilen bulgulara göre, hanehalkı sayısının bir kişi artması yoksulluk olasılığını yüksek oranda arttırmaktadır. Ancak bu bulguya temkinli yaklaşmak uygun olacaktır. Bu çalışmada aile bireyleri aile gelirinden aldıkları pay açısından homojen kabul edilmiştir. Yani bir aile sorumlusunun gelirden aldığı pay ile yeni doğmuş bir bebeğin aldığı pay eşit olduğu varsayılmıştır. Bu konuda bir ayrım yapabilmek için yeterli bilgiye ulaşılması durumunda daha farklı bir bulgunun ortaya çıkması mümkün olsa da özellikle düşük gelirli aileler için fazla nüfusun aile yoksulluğunu artırdığı çeşitli çalışmalarla kanıtlanmış bir gerçektir. Bu bulgu bir kez daha nüfus planlamasının haklılığını göstermektedir. Ayrıca Türkiye'de genç nüfus oranının yüksekliği bilinen bir gerçektir. Bir başka deyişle aile gelirine katkı sağlayamayacak yaştaki çocukların fazlalığı ailede kişi başına düşen gelirin azalmasına ve bu da yoksulluğa yol açmaktadır.

Çalışmadaki bir diğer bulguya göre, hanehalkı sorumlusunun yaşı gençten orta yaşa ya da orta yaştan yaşlılığa çıktığında yoksulluk olasılığı önemli derecede azalmaktadır. Yaş arttıkça bireylerin yapmış oldukları birikimlerin ve yatırımların artmış olması muhtemeldir. Bu da faiz, kar payı ve kira gibi ek gelirlerinin mevcudiyeti anlamına gelmektedir. Toplam aile gelirinin fazlalığına ilaveten hanehalkı sorumlusunun hayat tecrübesi nedeni ile ailedeki harcamaların daha bilinçli yapıllyor olması da ileri yaş grubunda daha yüksek bir refah düzeyi anlamına gelebilir. Bunun aksine bireylerin genç yaşlarda düşük gelirleri olmasına rağmen yeni bir düzen oluşturmanın gerektirdiği ilave harcamalar ve evlilik harcamalarının getirdiği borçların da bu yaş grubunda yoksulluk olasılığını daha da arttırdığı bilinen bir gerçektir.

Hanehalk1 sorumlusu kadın olan ailelerin ise yoksul olma olasılı̆ğ erkek olanlara göre çok daha düşük çıkmıştır. Ancak bu bulguyu yorumlarken örneklem içinde kadın aile sorumlusu oranının erkeklere göre çok düşük düzeyde kaldığı göz ardı edilmemesi gerekir. Ataerkil toplum düzeninin hüküm sürdüğü Türkiye'de hanehalkı sorumlusu büyük çoğunlukla erkek olarak açıklanmaktadır. Hanehalkı sorumlusunun kadın olduğu durumlar ise genellikle hiç evlenmemiş, eşi ölmüş veya boşanmış olanlardır. Eğitimli ve meslek sahibi olup evlenmemiş kadınlar kendi hanelerinin sorumlusu olarak daha yüksek refah düzeyinde yaşayabilirler. Boşanmış veya eşi ölmüş olanlar için ise bu konuda net bir şey söylemek mümkün değildir. Çünkü yakın akrabalarından ya da miras yoluyla ek destek elde 
ediyor olabilirler. Burada bir diğer ayrıntı, hanehalkı sorumlusu kadın olan ailelerde daha bilinçli harcama ve daha etkin tasarruf ve yatırım yapıldığı algısıdır. Yapılan araştırmalarda kayg1 bozukluğunun yaşam boyu sıklık oranının kadınlarda erkeklere göre yaklaşık iki kat fazla olduğu tespit edilmiştir (Peterson ve Reiss, 1993; Amerikan Psikiyatri Birliği, 2000; Yeşilbaş, 2008). Bu bulgu göz önünde bulundurulduğunda, kadının stres ve kaygı faktörünün erkeklere göre daha yüksek olması gelecek kaygısına ve bu da harcama, yatırım ve birikimlerinde daha akılcı davranmalarına sebep olabilmektedir.

Hanehalkı sorumlusu iş aramakta olanların yoksul olma olasılığı halen bir işte çalışmakta olanlara göre daha yüksektir. Aslında işsiz olmak doğrudan yoksulluk anlamına gelmemektedir. Çünkü işsiz olan kişinin çeşitli yan gelir kaynakları olabilir. Fakat bu bulgu Türkiye'de bireylerin yeterli ve çeşitli gelir kaynaklarının bulunmadığını düşündürmektedir. $\mathrm{Bu}$ sebeple eğer mümkünse bireylerin tasarruf alışkanlıklarının geliştirilmesi ve tasarrufu teşvik edici çeşitli önlemler alınması bu konuda olumlu bir adım olacaktır.

Hanehalkı sorumlusunun eğitim seviyesi arttıça yoksul olma olasılığı azalmaktadır. Eğitim seviyesinin artması genellikle daha yüksek gelirli iş anlamına gelmektedir. Eğitim seviyesi yüksek olan bireyler yüksek gelirlerine ilaveten gerek harcama ve gerekse de yatırım ve birikimlerinde daha rasyonel davranarak refah düzeylerini yükseltip yoksulluğa düşme olasılıklarını azaltabilmektedirler.

Hanehalkı sorumlusunun genel sağlık durumunun kötüleşmesi yoksul olma olasıllı̆ğnı arttırmaktadır. Hanehalkı sorumlusunun sağlık durumunun kötüleşmesi işsiz kalma olasılığını arttırmakta ve bu da ailenin toplam gelirini azaltmaktadır. Ayrıca sağlı harcamalarının artması dolayısıyla da ailenin harcanabilir geliri azalmakta ve bu da yoksulluğu arttırabilmektedir. Ülkede koruyucu sağlık hizmetlerinin arttırılması, bireylerin sağlık konusunda bilinçlendirilmeleri, devletin sağlık harcamalarına katkısının artırılması ve sağlık sigortalarının kapsamının ve koşullarının iyileştirilmesi bu konuda faydalı önlemler olacaktır.

Çalışmada yoksulluk olasıllı̆ğın en fazla arttıran demografik etmen hanehalkı sorumlusunun halen bir işte çalışmayıp iş arıyor oluşudur. Yoksulluk olasılığını arttıran diğer etmenler ise sırasıyla hane nüfusunun artması ve hanehalkı sorumlusunun genel sağlı durumunun kötüleşmesidir. Yoksulluk olasılığını azaltan etmenler ise önem sırasına göre hanehalkı sorumlusunun eğitim seviyesinin artması, hanehalkı sorumlusunun kadın olması ve yaşının artması olarak bulunmuştur.

$\mathrm{Bu}$ çalışmanın en önemli kısıtı 2017 yılı verilerinin kullanılması ve dolayısı ile elde edilen bulguların sadece bu yıla ait olmasıdır. Gelecek çalışmalarda analizlerin farklı yıllar için tekrarlanması veya panel veri analizinin kullanılması ile daha zengin ve genellenebilir bulgular elde edilebilecektir. Çalışmanın bir diğer kısıtı ise kullanılan değişkenlerin hepsinin eşit öneme sahip olduklarının kabul edilmesidir. Çeşitli ağırlıklandırma yöntemleri ile değişkenlerin önem dereceleri belirlenip daha kapsamlı bulgular elde edilebilir. Ayrıca bu çalışmayı diğer çalışmalardan ayıran en önemli özellik 
Yönetim ve Ekonomi Araștirmalarl Dergisi / Journal of Management and Economics Research

Cilt/Volume: 19 Sayl/Issue: 1 Mart/March 2021 ss./pp. 77-87

T. Y. Ayan, N. Değirmenci, Doi: http://dx.doi.org/10.11611/yead.675290

hanehalkının tamamının değil hanehalkı sorumlusunun demografik özelliklerinin dikkate alınmasıdır. Gelecek çalışmalarda bütün bireylerin özellikleri dikkate alınarak analizler tekrarlanabilir. Böylece hanehalkı üyelerinin tamamının özelliklerinin yoksulluk olasılığı üzerindeki etkileri belirlenebilir.

\section{KAYNAKÇA}

Achia, T.N.O., Wangombe, A. ve Khadioli, N. (2010) “A Logistic Regression Model to Identify Key Determinants of Poverty Using Demographic and Health Survey Data", European Journal of Social Sciences, 13(1): 38-45.

Alisjahbana, A. ve Yusuf, A.A. (2003) "Poverty Dynamics in Indonesia: Panel Data Evidence, Working Paper in Economics and Development Studies", https://ideas.repec.org/p/unp/wpaper/ 200303.html, (05.11.2019).

Alkire, S., Foster, J. E., Seth, S., Santos, M. E., Roche ve J.M. ve Ballon, P. (2015) "Multidimensional Poverty Measurement", https://www.ophi.org.uk/wp-content/uploads/ OPHIWP083Ch2.pdf, Oxford Poverty \& Human Development Initiative (OPHI) Working paper no:83, (10.12.2019).

Amerikan Psikiyatri Birliği (2000) "Mental Bozuklukların Tanısal ve Sayımsal El Kitabı”, Dördüncü Baskı (DSM-IV), Yeniden Gözden Geçirilmiş Tam Metin. Washington DC.

Aydın, K. ve T. Güloğlu. (2011) “Türkiye'de Nispi Yoksulluğun Sosyo-Ekonomik Analizi”, Sosyal Siyaset Konferansları Dergisi, 60: 89-118.

Dartanto, T. ve Nurkholis (2013) “The Determinants of Poverty Dynamics in Indonesia: Evidence from Panel Data", Bulletin of Indonesian Economic Studies, 49 (1): 61-84.

De La Rosa, M. (2008) “An Analysis of Latino Poverty and a Plan of Action”, Journal of Poverty, 4 (12): 27-62.

Değirmenci, N. (2020) "Hanehalkı Sorumlusunun Yoksulluk Olasıllğını Etkileyen Demografik Özellikleri: Düzey 1 Bölgeleri”, İstanbul Ticaret Üniversitesi Sosyal Bilimler Dergisi, 19(39): 858-868.

Geda, A., Jong, N., Kimenyi, M.S. ve Mwabu, G. (2005) "Determinants of Poverty in Kenya: A Household Level Analysis", www.econ.uconn.edu/working/2005-44pdf, (11.10.2019).

Greeley, M. (1994) “Measurement of Poverty and Poverty of Measurement”, Institute of Developments Studies, 25(2): 50-58.

Islam, Md.D., Sayeed, J. ve Hossain, Md. N. (2017) "On Determinants of Poverty and Inequality in Bangladesh”, Journal of Poverty, 21(4): 352-371.

Kızılgöl, Ö. (2008) "Yoksulluğun Belirleyicileri: Türkiye Örneği”, Finans Politik \& Ekonomik Yorumlar, 45 (526): 79-92. 
Yönetim ve Ekonomi Araștirmalarl Dergisi / Journal of Management and Economics Research

Cilt/Volume: 19 Sayl/Issue: 1 Mart/March 2021 ss./pp. 77-87

T. Y. Ayan, N. Değirmenci, Doi: http://dx.doi.org/10.11611/yead.675290

Limanl, Ö. (2015) “Intertemporal Poverty in Turkey, Procedia Economics and Finance”, 30: 487-497.

Saidatulakmal, M., Abdelhak, S. ve Norma, M. (2018) "Trend of Poverty among Elderly: Evidence from Household Income Surveys", Journal of Poverty, 22(2): 89-107.

Mukherjee, S. ve Benson, T. (1998) “The Determinants of Poverty in Malawi”, World Development, 31(2): 339-358.

Okwi, P.O., Ndeng'e, G., Kristjanson, P., Arunga, M., Notenbaert, A., Omolo, A., Henninger, N., Benson, T., Kariuki, P. ve Owuor, J. (2007) "Spatial Determinants of Poverty in Rural Kenya", https://www.pnas.org/content/pnas/104/43/16769.full.pdf (12.01.2020).

Peterson, R.A. ve Reiss, S. (1993) “Anxiety Sensitivity Index Revised Text Manual”, Worthington: IDS Publishing Corp.

Rajaram, R. (2009) "Female-Headed Households and Poverty: Evidence from the National Family Health Survey", https://www.frbatlanta.org/-/media/Documents/news/conferences/2009/3rdinternational-economics/093rdseinternationaleconomicspaperrajaram.pdf, (20.02.2021).

Roberts, B.J. (2001) "Chronic and Transitory Poverty in Post-Apartheid South Africa Evidence from KwaZulu-Natal”, Journal of Poverty, 5(4): 1-28.

Rodriguez, J.G. (2015) "The Determinants of Poverty in the Mexican States of the US-Mexico Border", Estudios Fronterizos, 17(33): 141-167.

Sadiq, M. (2010) "Determinants of Poverty in Pakistan", Hamburg Review of Social Sciences, 4(3): 193-2013.

Sekhampu, T.J. (2012) "Poverty in a South African Township: The case of Kwakwatsi”, African Journal of Business Management, 6(33): 9504-9509.

Shirazi, N.S. (1995) “Determinants of Poverty in Pakistan", Economic and Social Review, 33(1/2): 91 101.

Şengül S. ve Fisunoğlu H. M. (2012) “Adana Kentsel Kesiminde Yoksulluk ve Yoksulluğun Belirleyicileri”, İktisat, İşletme ve Finans, 27: 59-84.

Topalhan, T. ve Yeşilkaya, F. (2017) “Kadın Yoksulluğunu Etkileyen Faktörlerin Panel Veri Analizi ile Belirlenmesi”, Karatahta İş Yazıları dergisi, 9: 1-27.

United Nations (2017) "Guide on Poverty Measurement", https://www.unece.org/fileadmin/ DAM/stats/publications/2018/ECECESSTAT20174.pdf, (11.12.2019).

Whelan, C.T, Nolan, B. ve Maître, B. (2014) "Multidimensional Poverty Measurement in Europe: An Application of the Adjusted Headcount Approach", Journal of European Social Policy, 24(2): 183-197. 
Wright, R. E. (1996) “Standardized Poverty Measurement”, Journal of Economic Studies, 23 (4): 3-17.

Yeşilbaş, D. (2008) "Majör Depresyon Tanısı Konulan Kişilerin Depresyonlarını İfade Biçimleri”, (Uzmanlık Tezi), İstanbul.

\begin{tabular}{|c|c|c|}
\hline $\begin{array}{c}\text { KATKI ORANI / } \\
\text { CONTRIBUTION } \\
\text { RATE }\end{array}$ & $\begin{array}{l}\text { AÇIKLAMA / } \\
\text { EXPLANATION }\end{array}$ & $\begin{array}{l}\text { KATKIDA BULUNANLAR / } \\
\text { CONTRIBUTORS }\end{array}$ \\
\hline $\begin{array}{l}\text { Fikir veya Kavram / } \\
\text { Idea or Notion }\end{array}$ & $\begin{array}{l}\text { Araştırma hipotezini } \\
\text { veya fikrini oluşturmak / } \\
\text { Form the research } \\
\text { hypothesis or idea }\end{array}$ & $\begin{array}{l}\text { Tuğba YAKICI AYAN } \\
\text { Nurdan DEĞİRENCİ }\end{array}$ \\
\hline Tasarım / Design & $\begin{array}{c}\text { Yöntemi, ölçeği ve } \\
\text { deseni tasarlamak / } \\
\text { Designing method, scale } \\
\text { and pattern }\end{array}$ & $\begin{array}{l}\text { Tuğba YAKICI AYAN } \\
\text { Nurdan DEĞİRMENCI }\end{array}$ \\
\hline $\begin{array}{l}\text { Veri Toplama ve } \\
\text { İşleme / Data } \\
\text { Collecting and } \\
\text { Processing }\end{array}$ & $\begin{array}{l}\text { Verileri toplamak, } \\
\text { düzenlenmek ve } \\
\text { raporlamak / Collecting, } \\
\text { organizing and } \\
\text { reporting data } \\
\end{array}$ & $\begin{array}{l}\text { Tuğba YAKICI AYAN } \\
\text { Nurdan DEĞİRMENCI }\end{array}$ \\
\hline $\begin{array}{c}\text { Tartışma ve Yorum / } \\
\text { Discussion and } \\
\text { Interpretation }\end{array}$ & $\begin{array}{l}\text { Bulguların } \\
\text { değerlendirilmesinde ve } \\
\text { sonuçlandırılmasında } \\
\text { sorumluluk almak / } \\
\text { Taking responsibility in } \\
\text { evaluating and } \\
\text { finalizing the findings }\end{array}$ & $\begin{array}{l}\text { Tuğba YAKICI AYAN } \\
\text { Nurdan DEĞİRMENCİ }\end{array}$ \\
\hline $\begin{array}{l}\text { Literatür Taraması / } \\
\text { Literature Review }\end{array}$ & $\begin{array}{l}\text { Çalışma için gerekli } \\
\text { literatürü taramak / } \\
\text { Review the literature } \\
\text { required for the study }\end{array}$ & $\begin{array}{l}\text { Tuğba YAKICI AYAN } \\
\text { Nurdan DEĞİRMENCI }\end{array}$ \\
\hline
\end{tabular}

Hakem Değerlendirmesi: Dış bağımsız.

Çıkar Çatışması: Yazar çıkar çatışması bildirmemiştir.

Finansal Destek: Yazar bu çalışma için finansal destek almadığını beyan etmiştir.

Teşekkür: -

Peer-review: Externally peer-reviewed.

Conflict of Interest: The author has no conflict of interest to declare.

Grant Support: The author declared that this study has received no financial support.

Acknowledgement: - 